\title{
A Comparative Evaluation of Stress Resistance Between Nano-hybrid Composite and Ormocer Restorations on Posterior Teeth - in vitro Study
}

\author{
ANTONIS S. PERDIOU ${ }^{1}$, ROZAN ALAM ELDIN ${ }^{1}$, KARIN ROXANA HAJAJ ${ }^{2}$, \\ MIHAI ROMINU ${ }^{3}$, COSMIN SINESCU ${ }^{3}$, MEDA LAVINIA NEGRUTIU ${ }^{3}$, \\ RADU MARCEL NEGRU ${ }^{4 *}$, TAREQ HAJAJ ${ }^{3}$ \\ ${ }^{1}$ Victor Babes University of Medicine and Pharmacy, Faculty of Dentistry, 2 Eftimie Murgu Sq., 300041, Timisoara, \\ Romania \\ ${ }^{2}$ Louis Turcanu Emergency Hospital for Children, 2 Doctor Iosif Nemoianu, 300011, Timisoara, Romnania. Victor Babes \\ University of Medicine and Pharmacy, Faculty of General Medicine, Department XIV, 2 Eftimie Murgu Sq, 300041, \\ Timisoara, Romania \\ ${ }^{3}$ Victor Babes University of Medicine and Pharmacy, Faculty of Dentistry, Department I, 2 Eftimie Murgu Sq., 300041, \\ Timisoara, Romania \\ ${ }^{4}$ Politehnica University Timisoara, Department of Mechanics and Strength of Materials, 2 Victoriei, Sq., 300006, Timisoara, \\ Romania
}

Abstract: Composite resin materials for posterior restorations are becoming more and more popular. According to the market, Ormocer materials are more expensive than composite resin this paper is comparing the resistance to fracture between nanohybrid composites and Ormocers under vertical forces to evaluate their cost efficiency in the dental cabinets. 20 teeth were prepared and filled with Ormocer and 20 with nanohybrid composite respectively. All the samples were sent for measuring under vertical pressure with the use of a universal testing machine. The average value of fracture for Ormocer was slightly higher $(1541 \mathrm{~N})$ than the average value of fracture of the nanohybrid composite $(1431 \mathrm{~N})$. Considering the similarity in the average values of the two materials we should look into the other properties (biocompatibility, shrinkage, aesthetics, etc) to take a final decision. Both materials can be used with the same rate of success taking in account always the protocol provided by the manufacturer.

Keywords: ormocer, nanohybrid composite, posterior teeth, stress resistance

\section{Introduction}

The biggest challenge dentistry is assigned to solve is the elimination of the accumulation of plaque which eventually may lead to dental carious lesions. In April 2012, The World Health Organization (WHO) published the alarming results of their own research stating that $60-90 \%$ of school children and almost $100 \%$ of adults have dental decays worldwide [1]. More alarming is the fact that around $60 \%$ of the lesions occur in pits and fissures $[2,3]$. Resin composite materials allow the adoption of minimal intervention approaches that conserve and preserve sound tooth structure, being biocompatible, esthetic and having many other useful mechanical properties. Hence restorative dentistry is making a gradual transition towards resin composites, rather than dental amalgam [4].

The necessity of innovations and advancements in dental resin composite materials led to the era of many different types of composites. Some manufacturers (BRILLIANT ${ }^{\text {TMNG- Coltene and FILTEK }}{ }^{\text {TM }}$ Z350XT 3M/ESPE) changed their products by reducing the particles size and they lunch the nano-hybrid composites. Nano-hybrid composites are made by combining micro-hybrid particles $(0.6-1 \mu \mathrm{m}+40 \mathrm{~nm})$ and nanofilled particles $(1-100 \mathrm{~nm})$. Their properties are similar and in some cases better than microhybrid but inferior to those of nanofilled [5]. They can be composed by Bis-GMA (bisphenol-A glycidyl dimethacrylate); UDMA (urethane dimethacrylate); Bis-EMA (bisphenol-A ethoxylated dimethacrylate); TEGDMA (triethylene glycol dimethacrylate) and their filler can be prepolymer, silica, $\mathrm{TiO}_{2}$ (Titanium Oxide), Ba-B-F-Al-Si glass $(0.02-1 \mu \mathrm{m}$, $75 \mathrm{wt} \%$ ) and a handful of other material of the manufacturer choice [6]. Other manufacturers direct their attention

*email: radu.negru@upt.ro 
to the composition of the composites incorporating ceramic particles producing ormocers. Ormocer is described as three dimensionally cross linked co-polymers with multipolymerization with no residual unreacted monomers and combines the surface properties of the silicones, the toughness of the organic polymers and the hardness and thermal stability of ceramics. A disadvantage of ormocer materials is the lower adaptation properties than composites [7-10]. On the other hand, it was found that the shrinkage of ormocer was equal to that of hybrid composites despite having less filler content. The authors [14] attributed their findings to the difference in the resin matrix of ormocer [11]. As a result, it was suggested that the advantages of ormocers include amongst others: low shrinkage (1.97 vol\%), high abrasion resistance (compressive strength of $410 \mathrm{Mpa}$ ), biocompatibility, protection against caries, does not liberate any residual monomer after polymerization and has a better manipulation [12]. Ormocer materials have multiple indications in dentistry such as direct restoration for all types of cavities, cosmetic veneers, protective sealant for child teeth, protective varnish as caries prophylaxis and as orthodontic bonding adhesive [13,14]. It is believed that the ormocer material is an excellent option for posterior restorations. The plethora of materials in the market led to confusion between dental professionals regarding which ones should they use and, therefore, the purpose of the present research is to sort out which composite of the aforementioned is more resistant to the occlusal forces.

\section{Materials and methods}

Forty posterior teeth (20 molars and 20 premolars) were prepared by the same operator using high speed handpiece with an inverted cone producing cavities with volume of $12 \mathrm{~mm}^{3}$ (Figure 1). The specimens were prepared using universal total etch and bonding ( $5^{\text {th }}$ generation adhesives). Afterwards, using A3 shade nanohybrid composite and ormocer respectively, we filled the cavities and light curing for 20 seconds each time until we reach the occlusal surface. The nanohybrid material used was Filtek ${ }^{\mathrm{TM}}$ Z350 XT (3M/ESPE) which is composed by two components: the organic phase made of UDMA, Bis-EMA, Bis-GMA and TEGDMA and the inorganic matrix made of Silica $20 \mathrm{~nm}$ nonagglomerated/aggregated), zirconia $(4-11 \mathrm{~nm}$ nonagglomerated/ aggregated and agglomerated) clusters, zirconia/ silica aggregated particles (20 nm silica particles combined with 4-11 nm zirconia 3) [15]. The Ormocer that was used was ADMIRA Ormocer®-based restorative composite (VOCO GmbH, Germany) made of inorganic-organic co-polymers and inorganic silanated filler particles. It is synthesized through a solution and gelation process from multifunctional urethane and thioether(meth)acrylate alkoxysilanes. The Ormocer matrix consists of ceramic polysioxane and added polymerisable side chains. The filler particles are 1-1.5 $\mu \mathrm{m}$ in size. The material presents $77-78 \mathrm{wt} . \%$ of filler loading, $61 \%$ filler volume and a modulus of elasticity of 10.700MPA according to the manufacturer [16]. Finally all the specimens were polished with resin polishing burs mounted on a low speed handpiece (Figure 2).

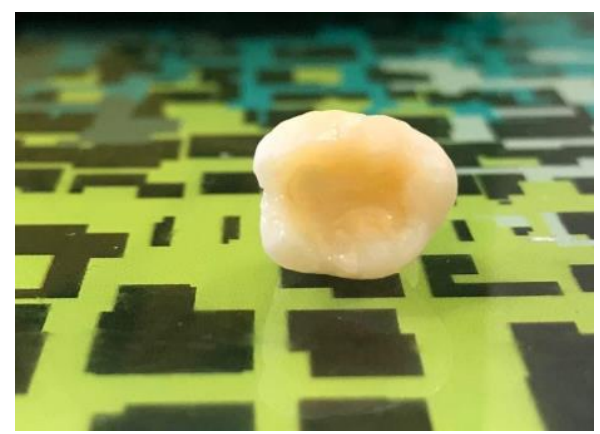

Fig. 1. Specimen preparation

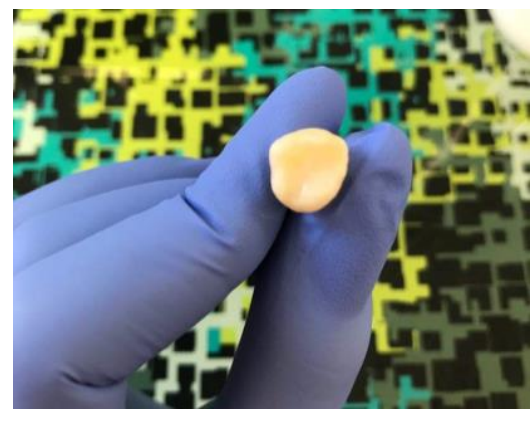

Fig. 2. Specimen after polishing

Epoxy resin (ARALDITE AW 106 and HARDENER HV 953 U BD) was used to stabilize the teeth and to simulate the situation in the oral cavity. Afterwards pressure, perpendicular to the occlusal surface, was applied. The measurements were taken by the universal testing machine ZWICK/ROELL Z005, manufactured in Germany, with speed of $2 \mathrm{~mm} / \mathrm{min}$ while out of contact and with speed of $1 \mathrm{~mm} / \mathrm{min}$ after the contact with the specimen (Figure 3). 

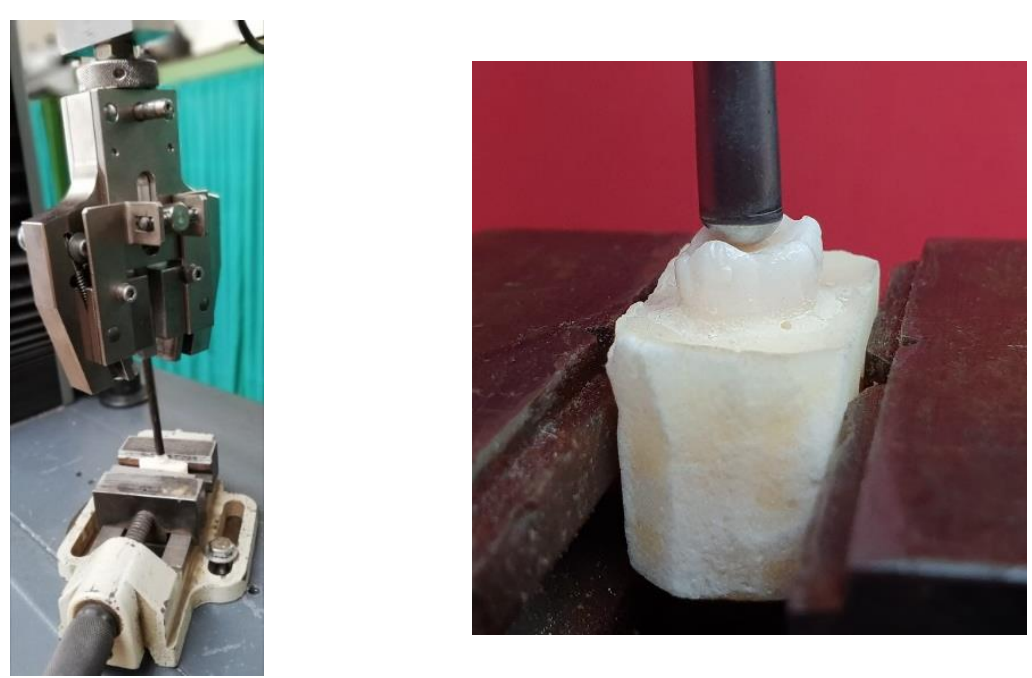

Fig. 3. ZWICK/ROELL ZOO5 universal testing machine

\section{Results and discussions}

The fracture value was taken when a fracture was noted by the machine's software or was first seen in the composite material. The average value was considerably lower in premolars for both materials $-980 \mathrm{~N}$ with Standard Deviation (SD) 27.46 for Ormocer and $583 \mathrm{~N}$ with SD 9.62 for nanohybrid, while in molars it was $2103 \mathrm{~N}$ with SD 280.75 and $2278 \mathrm{~N}$ with SD 207.85 respectively (Figure 4). The average value of ORMOCER was slightly higher - $1541 \mathrm{~N}$ with SD 608.07, while the one of nanohybrid composite was $1431 \mathrm{~N}$ with SD 881.03 (Figure 5). The standard deviation for ORMOCER and nanohybrid composite is very high (608.07 and 881.03 respectively) due to the fact we took in account both molars and premolars and they have different characteristics such as in geometry and number of roots. In this study the minimum fracture value for Ormocer was $947 \mathrm{~N}$ while for the nanohybrid was $572 \mathrm{~N}$ and the maximum fracture value was $2610 \mathrm{~N}$ and $2590 \mathrm{~N}$ respectively. In Table 1 we can observe the fracture value for every individual specimen of Ormocer and in Table 2 as well as for nanohybrid composite. The fracture line in ORMOCER restoration appears in figure 6 and for nanohybrid restoration in figure 7.

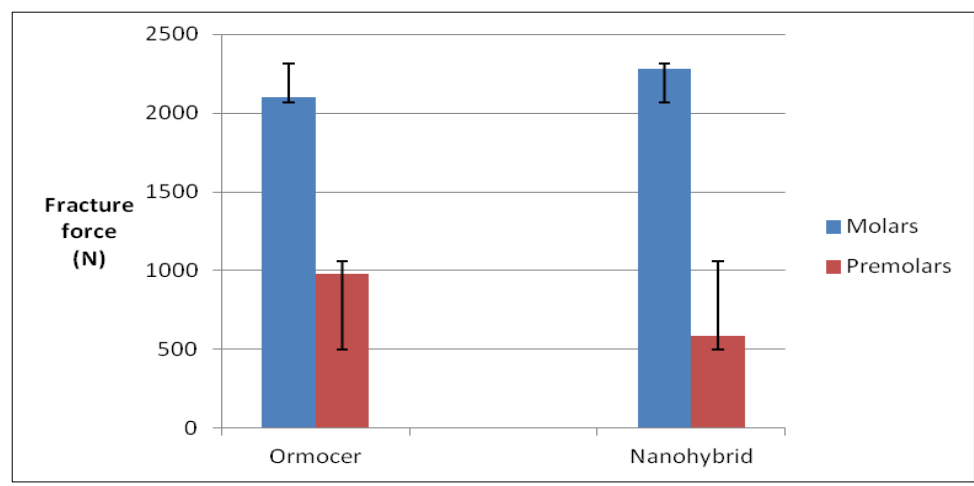

Fig. 4. Average fracture force for molars and premolars

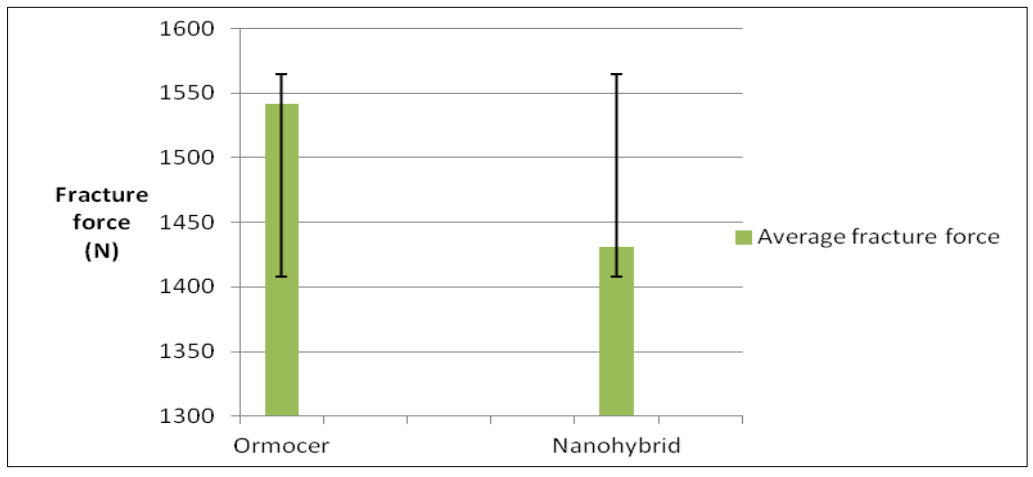

Fig. 5. Average fracture force as a function of filling material 
Table 1. Individual Fracture value for Ormocer

\begin{tabular}{|c|c|c|c|c|c|}
\hline $\begin{array}{c}\text { Individual fracture values for } \\
\text { molars with Ormocer restoration } \\
(\mathrm{N})\end{array}$ & 2610 & 2470 & 2200 & 2150 & 2100 \\
\cline { 2 - 5 } & 2050 & 2000 & 1950 & 1850 & 1650 \\
\hline $\begin{array}{c}\text { Individual fracture values for } \\
\text { premolars with Ormocer } \\
\text { restoration (N) }\end{array}$ & 1030 & 1010 & 1000 & 990 & 980 \\
\cline { 2 - 6 } & 970 & 960 & 960 & 950 & 947 \\
\hline
\end{tabular}

Table 2. Individual Fracture value for Ormocer

\begin{tabular}{|c|c|c|c|c|c|}
\hline $\begin{array}{c}\text { Individual fracture values for } \\
\text { molars with Nanohybrid } \\
\text { restoration (N) }\end{array}$ & 2590 & 2500 & 2495 & 2405 & 2280 \\
\cline { 2 - 6 } & 2200 & 2100 & 2150 & 2060 & 2000 \\
\hline $\begin{array}{c}\text { Individual fracture values for } \\
\text { premolars with Nanohybrid } \\
\text { restoration (N) }\end{array}$ & 600 & 595 & 590 & 590 & 580 \\
\cline { 2 - 6 } & 580 & 577 & 575 & 575 & 572 \\
\hline
\end{tabular}

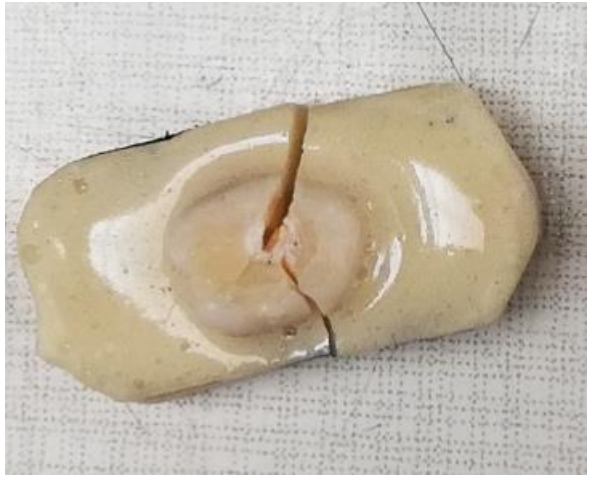

Fig. 6. Fracture line in a molar with Ormocer restoration

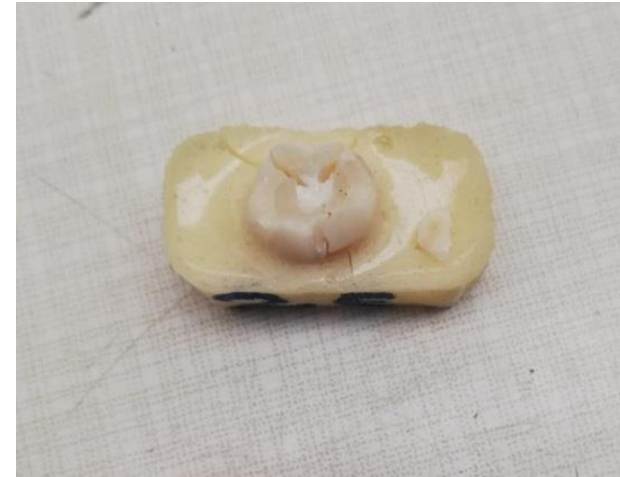

Fig. 7. Fracture line in a molar with nanohybrid restoration

The environment in the oral cavity is dynamic and very complex. Masticatory forces are depended in many factors and amongst them we enumerate age, gender, food type, jaw disorders, tooth quality and muscular strength. The masticatory forces can vary from $505 \mathrm{~N}$ to $900 \mathrm{~N}$, for males, with an average value of $700 \mathrm{~N}$ and, for females, from $315 \mathrm{~N}$ to $777 \mathrm{~N}$ with an average value of $533 \mathrm{~N}$. Common foods such as carrots, biscuits, and cooked meats produce forces in the range of 70-150 $\mathrm{N}$ on a single tooth [16]. 80\% of our specimens had a fracture originating within the material where the other $20 \%$ had the fracture originating from the tooth itself. The results of this study are in concordance with a study from Mohit et al (2018) demonstrating that Ormocer is more resistant than ceramic inlays and nanohybrid when restoring premolars [17]. A 3-year prospective clinical trial of nanohybrid restorations in molars and premolars showed acceptable clinical performance, from 31 restorations 1 had to be replaced [18]. On the other hand another 3-year clinical trial revealed that Ormocer had an excellent clinical performance without showing unacceptable wear pattern when used in posterior restorations [19]. Having said that, resistance to fracture is not the only property we need to take in consideration while we are choosing our restorative material. Tomar and Choudhary (2018) compared Ormocer based materials with dimethacrylate based composites. They measured the volumetric shrinkage by measuring specific gravities between cured and uncured specimens and dimethacrylate composites had higher average volumertric shrinkage (2.69\% with SD 0.78) than Ormocer (1.85\% with SD 0.22). In addition they compared the elastic modulus by curing the samples and then load them to a universal machine (Banbros Computerised UTM, WDW-5) and then submitted to a gradual loading up to $1000 \mathrm{~N}$ with a crosshead speed set at $1 \mathrm{~mm} / \mathrm{min}$. Dimethacrylate composites had higher average elastic modulus (687.21 MPa with SD 104.14) than Ormocer (469.91 MPa with SD 54.30). The last property the authors tested was the flexural strength using bar shaped specimen with uniform consistency and then cured. The specimens were submitted to three-point bend testing in a universal machine at a crosshead speed of $0.5 \mathrm{~mm} / \mathrm{min}$. 
The distance between the supports was $10 \mathrm{~mm}$. Higher average flexural strength was found in dimethacrylate composites (349.35 MPa with SD 78.59) than Ormocers (330.92 MPa with SD 60.55). All the statistical tests were made using One-way ANOVA and they were all statistically significant $(\mathrm{p}<0.05)$ for every property between the samples [21].

\section{Conclusions}

On the basis of the results of this study we can conclude that ormocer has a higher resistance than the nanohybrid composite. Nevertheless both materials can be effectively used with excellent prognosis, against fracture, in posterior teeth restorations. To assess the overall superiority of one material it's indispensable to evaluate more of material's properties like fatigue, biocompatibility and microleakage, module of elasticity, flexural strength, wear resistance and volumetric shrinkage etc. Clinically, it's vital that all the proprieties are taken into consideration when choosing the proper material for a restoration. Not all cases are the same and so, not all treatment plans work for all the patients. From this perspective, other qualities of the materials, besides wear and fracture resistance, can influence the decision making process.

Acknowlegments: This article was presented at Polymer Processing in Engineering Conference - PPE 2019, 7- 9 October 2019, Galati - Romania.

\section{References}

1. HIREMATH A., MURUGABOOPATHY V., ANKOLA V.A., HEBBAL M., MOHANDOSS S., PASTAY P.,

J. Clin. Diagn. Res., 10, no. 10, 2016, p. 47.

2. BOURZGUI F., SEBBAR M., HAMZA M., Orthodontics and Carries, Chapter in Principles in contemporary orthodontics, InTech, InTech Europe, 2011, ISBN: 978-953-307-687-4.

3. CHAUSSAIN C., OPSAHL VITAL S., VIALLON V., VERMELIN L., HAIGNERE C., SIXOU M., LASFARGUES JJ., Clin. Oral Investig., 14, no. 2, 2010, p. 177.

4. TUNCER S., DEMIRCI M., OZTAŞ E., TEKÇE N., UYSAL Ö., Restor. dent. endod, 42, no. 4, 2017, p. 253.

5. ALZRAIKAT H., BURROW F M., MAGHAIREH A. G., TAHA A N., Oper. Dent., 43, no. 4, 2018, p. E173.

6. MORAES R. R., GONÇALVES L. S., LANCELLOTTI A. C., CONSANI S., CORRER-SOBRINHO L., SINHORETI MA., Oper. Dent., 34, no. 5, 2009, p. 551.

7. WATTS D.C., MAROUF A.S., Dent. Mater., 16, no. 6, 2000, p. 447.

8. YAP A.U., TAN C.H., CHUNG S.M., Oper. Dent., 29, no. 3, 2004, p. 269.

9. TAGTEKIN D.A., YANIKOGLU F.C., BOZKURT F.O., KOLOGLU B., SUR H., Dent. Mater., 20, no. 5, 2004, p. 487.

10. AJLOUNI R., BISHARA S.E., SOLIMAN M.M., OONSOMBAT C., LAFFOON J.F., WARREN J., Angle Orthod., 75, no. 1, 2005, p. 106.

11. CATTANI-LORENTE M., BOUILlAGUET S., GODIN C.H., MEYER J.M., Eur. Cell. Mater., 1, no. 1, 2001, p. 25.

12.HICKEL R., DASCH W., JANDA R., TYAS M., ANUSAVICE K., Int. Dent. J., 48, no. 1, 1998, p. 3.

13. HENNIG A.C., HELBIG EB, HAUFE E, RICHTER G, KLIMM HW, Schweiz Monatsschr Zahnmed, 114, no. 2, 2004, p. 104.

14. DA ROSA M. G., DA SILVA M. L., DE MENEZES M, DO VALE H., Eur. Dent. J., 10, no. 2, 2016, p.170.

15. KALRA S., SINGH A., GUPTA M., CHADHA V., Contemp. Clin. Dent., 3, no. 1, 2012, p.48.

16. ROSIN M., STEFFEN H., KONSCHAKE C., GREESE U., TEICHMANN D., HARTMANN A., MEYER

G., Clin. Oral. Investig., 7, no. 1, 2003, p. 20.

17. MCGARRY J., SPANGENBERGER A., Dynamic evaluation of forces during mastication. In partial fulfillment of the degree of Bachelor of Science, Worchester Polytechnic institute.

18. GUNWAL K. M., SHENOIB R.P., PARANJAPEC T., DHOTED S., TONGYAE R., KUMARF M., RASTOGI S., J. Oral. Biol. Craniofac. Res., 8, no. 2, 2018, p.134.

19. CELIK Ç., ARHUN N., YAMANEL K., Med. Princ. Pract., 23, 2014, p. 453.

20. MAHMOUD S.H., EL-AMBABY A.E., ABDALLAH A.M., Oper. Dent., 39, no. 1, 2014, p. 32.

21. TOMAR H., CHOUDHARY E., J. Appl. Dent. Med. Sci., 17, no. 5, 2018, p. 51.

Manuscript received: 24.02 .2020 